\title{
Study on genetic variability in some agro-morphological traits of Brassica rapa L. (Brown sarson) germplasm characterized under rainfed conditions of Kashmir, India
}

\author{
Sheikh Mohammad Sultan \\ ICAR-National Bureau of Plant Genetic Resources, Regional Station Srinagar, Srinagar-190007(J \& K), INDIA \\ E-mail: sheikhmsultan@gmail.com
}

Received: August 10, 2016; Revised received: June 10, 2017; Accepted: October 26, 2017

Abstract: 36 Brassica rapa L. (Brown sarson) genotypes were characterized during two successive seasons of 2013/14 and 2014/15 along with two national checks (Puas Kalyani and GSL-2) and one local check variety (Shalimar-1) to assess the extent of variability and amount of variation in agro-morphological traits of plant height, number of primary branches/plant, days to $50 \%$ flowering, number of seeds/siliqua, seed yield/plant and 1000 -seed weight. Important traits of plant height varied from $58.35 \mathrm{~cm}-95.36 \mathrm{~cm}$, seed yield/plant from $3.840 \mathrm{~g}-18.470 \mathrm{~g}$ and 1000 -seed weight from $2.746 \mathrm{~g}-4.377 \mathrm{~g}$. Analysis of variance revealed significant differences at 0.05 level of probability among different genotypes for these characters during a particular year while differences were non-significant in all the traits excepting days to $50 \%$ flowering when data of the two years was compared. Highest variability, phenotypic coefficient of variation (33.89\%) and genotypic coefficient of variation $(30.99 \%)$ were recorded for the trait seed yield/plant. High heritability coupled with high to moderate per cent genetic advance was recorded for seed yield/plant and 1000-seed weight indicating that these traits can be improved through simple selection. Moderate heritability with low genetic advance was observed in all other traits suggesting greater influence of environment. Promising donor genotypes for all these traits have been identified for possible utilization in breeding programmes in the region.

Keywords: Brassica rapa L. (Brown sarson), Genetic advance, Genetic variability, Germplasm, Heritability

\section{INTRODUCTION}

Oil seed Brassica commonly known as rapeseed and mustard occupies an important position in the rainfed agriculture of India being the third most important edible oilseed crop of the world after soybean and oil palm. In India, during the year 2014-2015 it was grown on an area of 6.6 million hectares with production of more than 8.3 metric tons and productivity of 125 kilograms per hectare; the states of Rajasthan, Haryana, Madhya Pradesh, Uttar Pradesh, West Bengal and Gujarat are the major producers of the crop in that order (DRMR, 2015). Rapeseed is among most important oil and protein rich annual crops in the world and Brassica rapa L. (Brown sarson) is one of the most important oleiferous Brassicas cultivated in the North Western regions of India (Singh et al., 2007). In the North Western Indian Himalayan state of Jammu and Kashmir it is a popular and only edible oil seed crop cultivated during rabi season under temperate conditions in Kashmir valley and in some high altitude regions of Jammu province. The oil seed crop in the state is grown on an area of 66,700 hectares with total production of 58,000 tones and productivity of 885 kilograms per hectare (Ministry of Agriculture and Cooperation GOI, 2015). However, during last few years area under cultivation of this crop in the entire state has shown a declining trend. Irrespective of this fact, however its production and productivity has increased over these years. Still the state of Jammu and Kashmir lags very much behind in oil seed production and productivity. In Kashmir valley Brown sarson is grown under harsh winter conditions covering an area of more than 47 thousand hectares generally sown during the months of September/October and harvested in May/June followed by paddy cultivation in crop rotation. The yields are disappointingly low and there is a dire need of developing high yielding genotypes of brown sarson to make its cultivation profitable in the state (Dar et al., 2013).Thus there is a tremendous scope for genetic improvement of brown sarson to develop high yielding varieties with stability in performance over a range of environments.

Genetic diversity is a prerequisite in crop improvement programmes. It aids in choosing parental materials to get maximum recombination in hybridization process (Arunachalam, 1981). Diversity in germplasm is fundamental in selecting superior genotypes having advantageous traits for utilization in hybridization in developing varieties with increased yield (Joshi and Dhawan, 1966) and wider adaptation, desirable quality, 
pest and disease resistance (Nevo et al., 1982).Besides genetic variability in the germplasm, the effectiveness of selection for a particular trait depends on degree of association that exists between different traits as well. Analysis of variability among the traits and the association of a particular character in relation to other traits contributing to yield of a crop would be of great importance in planning a successful breeding program (Mary and Gopalan, 2006).Genetic variation can be evaluated by morphological, biochemical and molecular markers techniques (Marjanovic-Jeromela et al., 2009). Morphological characterization continues to be the first step in the description and classification of germplasm.

The present study was therefore, undertaken to determine genetic variability and to find association among yield and some yield related traits in Brown sarson (Brassica rapa L.) germplasm which may be helpful in selection of superior genotypes for furthering oilseed crop improvement programmes in the state of Jammu and Kashmir.

\section{MATERIALS AND METHODS}

36 accessions of Brassica rapa L. (Brown sarson) germplasm collected from different parts of India and supplied by ICAR-National Bureau of Plant Genetic Resources, New Delhi along with one local (Shalimar1) and two national check varieties (Pusa Kalyani, GSL-2) were used in the present study. Genotypes were characterized during two successive rabi seasons of 2013/2014 and 2014/2015 with actual sowing dates of 26-10-2013 and 19-11-2014 respectively. The trials were laid out in a randomized complete block design with two replications each year at the Experimental Field of ICAR-NBPGR Regional Station Srinagar, Jammu and Kashmir (33 ${ }^{\circ} 59^{\prime} \mathrm{N}$ latitude, $74^{\circ} 47^{\prime} \mathrm{E}$ longitude, $1639 \mathrm{~m}$ above sea level, average monthly rainfall 52mm, soil; clay 33: silt 60: sand 7 and $\mathrm{pH}$ 6.23).Each genotype was sown by hand in a single row of $3 \mathrm{~m}$ length with spacing of $30 \times 10 \mathrm{cms}$ between and within rows respectively. Weeds were removed by hand prior to flowering stage and standard cultural practices were followed for raising the crop.Five plants were randomly selected and marked from each genotype ignoring those on the peripheries for recording data on plant height (cms), number of primary branches per plant, days to $50 \%$ flowering, number of seeds per siliqua, seed yield per plant (g) and 1000seed weight $(\mathrm{g})$.In order to estimate the extent of magnitude of variation among these traits, the data were subjected to analysis of variance for both the years individually as well as pooled data across two years. Components of variance; $\sigma^{2} \mathrm{~g}$ (genotypic variance), $\sigma^{2}$ $\mathrm{p}$ (phenotypic variance) and $\sigma^{2}$ e (error variance) were estimated using the following formulae (Wricke and Weber, 1986):

$\sigma^{2} \mathrm{~g}=(\mathrm{MSG}-\mathrm{MSE}) / \mathrm{r}$ $\sigma^{2} \mathrm{p}=\mathrm{MSG} / \mathrm{r}$

$\sigma^{2} \mathrm{e}=\mathrm{MSE} / \mathrm{r}$

MSG, MSE and $r$ are the mean square of genotypes, mean square of error and number of replications respectively

Genotypic Coefficient of Variation (GCV) and Phenotypic Coefficient of Variation (PCV) were determined using following formulae (Singh and Chaudhary, 1985):

$\operatorname{GCV}(\%)=\sqrt{ } \sigma^{2} \mathrm{~g} / \overline{\mathrm{X}} \times 100$

$\operatorname{PCV}(\%)=\sqrt{ } \sigma^{2} \mathrm{p} / \overline{\mathrm{X}} \times 100$

$\overline{\mathrm{X}}$ is the sample mean value

Broad sense heritability $\left(h^{2}\right)$ was estimated by the formula suggested by Allard (1999) as follows:

Heritability $\left(h^{2}\right)=\sigma^{2} g / \sigma^{2} p$

Expected Genetic Advance (GA) and percentage of GA was calculated by the following formulae (Allard, 1960; Singh and Chaudhary, 1985):

$\mathrm{GA}=\mathrm{K} \cdot \sqrt{\sigma^{2} \mathrm{p} \cdot \mathrm{h}^{2}}$

$\mathrm{K}$ is the constant with a value of 2.06 at $5 \%$ selection intensity

$\mathrm{GA}(\%)=\mathrm{GA} / \overline{\mathrm{X}} \times 100$

\section{RESULTS AND DISCUSSION}

The data recorded on different agro-morphological traits of 36 Brassica rapa L. genotypes and pooled across two years of 2013/2014 and 2014/2015 are presented in the Table 1.The results showed moderate to high variability for all the traits studied. The variability was highest in the trait seed yield/plant with coefficient of variation value of $33.89 \%$ followed by number of seeds/siliqua (13.41\%), number of primary branches/ plant $(12.12 \%)$, plant height $(11.31 \%)$ and 1000 -seed weight $(10.51 \%)$ in that order (Table 2). The extent of variability in the trait days to $50 \%$ flowering was, however not appreciable. Compared to best performing check varieties promising donor genotypes were identified for all the traits studied and are listed in Table 3.Yield components have significant role in the final yield performance of the plant, meaning that the indirect selection for traits that influence yield can be an effective approach in rapeseed breeding program (Sadat et al., 2010; Marjanovic-Jeromela et al., 2011).The mean values of different traits recorded during two separate years of 2013/2014 and 2014/2015 have been presented in Table 4.It is pertinent to mention here that compared to first year sowing time in second year was delayed by three weeks. The results show that early sowing is advantageous so far as traits of plant height, number of primary branches, number of seeds per siliqua and seed yield per plant are concerned resulting in comparatively higher values.The differences between the years were however not significant in all traits excepting days to $50 \%$ flowering. Interestingly $50 \%$ flowering occurred 11 days earlier in late sown crop than in the early sown crop; the difference being significant at 0.05 level of probability. 
Sheikh Mohammad Sultan / J. Appl. \& Nat. Sci. 9 (4): 2344 - 2349 (2017)

Table 1. Mean performance of 36 Brassica rapa L. (Brown sarson) genotypes grown during two seasons of 2013/2014 and 2014/2015 (combined data) under rainfed conditions of Kashmir.

\begin{tabular}{|c|c|c|c|c|c|c|c|}
\hline $\begin{array}{l}\text { S. } \\
\text { No. }\end{array}$ & Genotype & $\begin{array}{l}\text { Plant height } \\
(\mathrm{cms})\end{array}$ & $\begin{array}{l}\text { No. of pri- } \\
\text { mary } \\
\text { branches }\end{array}$ & $\begin{array}{l}\text { Days to 50\% } \\
\text { flowering }\end{array}$ & $\begin{array}{l}\text { No of seeds/ } \\
\text { siliqua }\end{array}$ & $\begin{array}{l}\text { Seed yield/ } \\
\text { plant }(g)\end{array}$ & $\begin{array}{l}\text { 1000- Seed } \\
\text { weight }(\mathrm{g})\end{array}$ \\
\hline 1 & IC-259339 & 58.35 & 2.4 & 165.7 & 6.55 & 5.727 & 3.792 \\
\hline 2 & IC- 338496 & 73.34 & 2.7 & 167.7 & 11.35 & 11.580 & 3.157 \\
\hline 3 & IC- 343127 & 74.97 & 2.8 & 168.0 & 10.15 & 15.732 & 2.943 \\
\hline 4 & IC- 371886 & 68.11 & 2.9 & 168.5 & 12.42 & 13.515 & 3.428 \\
\hline 5 & IC- 416883 & 68.96 & 2.8 & 167.7 & 12.00 & 9.405 & 3.670 \\
\hline 6 & IC- 491555-A & 79.72 & 2.6 & 168.0 & 10.70 & 12.410 & 3.987 \\
\hline 7 & EC- 657026 & 80.51 & 3.0 & 167.5 & 11.62 & 7.310 & 3.465 \\
\hline 8 & IC- 11765 & 85.50 & 3.4 & 166.2 & 11.35 & 15.265 & 3.550 \\
\hline 9 & IC- 212127 & 73.68 & 3.8 & 166.2 & 12.20 & 11.165 & 3.578 \\
\hline 10 & IC- 262076 & 76.54 & 3.5 & 166.0 & 13.55 & 11.907 & 3.397 \\
\hline 11 & IC- 262823 & 71.54 & 3.0 & 166.2 & 10.05 & 10.655 & 3.107 \\
\hline 12 & IC- 262824 & 64.52 & 3.0 & 165.7 & 13.30 & 12.702 & 3.414 \\
\hline 13 & IC- 280040 & 69.84 & 2.7 & 167.0 & 11.20 & 13.745 & 3.143 \\
\hline 14 & IC- 280042 & 75.28 & 3.4 & 167.2 & 15.45 & 10.675 & 3.267 \\
\hline 15 & IC- 280045 & 64.45 & 3.0 & 167.7 & 13.35 & 15.175 & 3.815 \\
\hline 16 & IC- 280048 & 71.92 & 3.1 & 167.2 & 11.85 & 16.850 & 3.293 \\
\hline 17 & IC- 298004 & 63.75 & 3.5 & 167.2 & 12.30 & 7.420 & 3.625 \\
\hline 18 & IC- 313175 & 78.06 & 3.3 & 167.0 & 13.45 & 3.840 & 3.859 \\
\hline 19 & IC- 332634 & 76.79 & 2.7 & 167.5 & 11.97 & 12.320 & 3.319 \\
\hline 20 & IC-363616-A & 90.08 & 3.2 & 167.5 & 10.30 & 9.550 & 3.727 \\
\hline 21 & IC- 363710 & 76.82 & 3.1 & 168.5 & 12.05 & 14.600 & 3.403 \\
\hline 22 & IC- 363713 & 75.93 & 2.8 & 168.2 & 12.86 & 10.545 & 2.746 \\
\hline 23 & IC- 363731 & 74.28 & 3.4 & 167.5 & 10.85 & 6.962 & 3.200 \\
\hline 24 & IC- 363733 & 81.06 & 4.0 & 167.0 & 14.25 & 11.535 & 4.156 \\
\hline 25 & IC- 363735 & 84.02 & 3.9 & 167.0 & 14.85 & 18.470 & 2.928 \\
\hline 26 & IC- 363739 & 71.28 & 3.2 & 165.7 & 11.15 & 15.465 & 3.389 \\
\hline 27 & IC- 363751 & 67.08 & 2.9 & 166.2 & 10.60 & 7.940 & 3.075 \\
\hline 28 & IC- 363752 & 58.80 & 2.7 & 166.0 & 11.13 & 6.855 & 3.188 \\
\hline 29 & IC-363771 & 95.36 & 3.2 & 166.2 & 11.60 & 6.470 & 3.679 \\
\hline 30 & IC- 363776 & 75.01 & 3.2 & 168.7 & 11.62 & 5.522 & 3.525 \\
\hline 31 & IC- 399823 & 82.57 & 3.5 & 167.5 & 11.00 & 9.997 & 4.377 \\
\hline 32 & IC- 399827 & 79.82 & 3.2 & 167.5 & 11.70 & 6.115 & 3.369 \\
\hline 33 & IC-538641 & 90.87 & 3.6 & 168.2 & 13.15 & 12.700 & 3.632 \\
\hline 34 & IC-553083 & 81.51 & 3.4 & 166.2 & 10.95 & 8.415 & 3.325 \\
\hline 35 & IC-553126 & 86.54 & 3.8 & 165.5 & 13.00 & 10.690 & 4.274 \\
\hline 36 & IC-223406-A & 71.56 & 3.0 & 165.7 & 13.70 & 6.245 & 3.469 \\
\hline
\end{tabular}

Table 2. Variability in some agro-morphological traits of 36 Brassica rapa L. (Brown sarson) genotypes grown during two seasons of 2013/2014 and 2014/2015 under rainfed conditions of Kashmir.

\begin{tabular}{lllllll}
\hline \multirow{2}{*}{ Trait } & \multirow{2}{*}{ Range } & \multirow{2}{*}{ Mean \pm SE } & \multirow{2}{*}{$\mathbf{C V}$} & \multicolumn{2}{c}{ Mean value of check varieties } \\
\cline { 6 - 7 } & & & Shalimar-1 & Pusa Kalyani & GSL-2 \\
\hline Plant height & $58.35-95.36$ & $75.51 \pm 1.42$ & 11.31 & 76.48 & 81.00 & 85.13 \\
No. of primary branches & $2.4-4.0$ & $3.2 \pm 0.06$ & 12.12 & 2.8 & 3.3 & 3.3 \\
Days to 50\% flowering & $165.5-168.7$ & $167.1 \pm 0.15$ & 0.55 & 166.9 & 167.1 & 166.6 \\
No. of seeds/ siliqua & $6.55-15.45$ & $11.93 \pm 0.27$ & 13.41 & 10.97 & 12.92 & 13.46 \\
Seed yield/ plant & $3.840-18.470$ & $10.708 \pm 0.605$ & 33.89 & 7.532 & 7.094 & 9.005 \\
1000-Seed weight & $2.746-4.377$ & $3.479 \pm 0.061$ & 10.51 & 3.918 & 3.386 & 3.479 \\
\hline
\end{tabular}

Table 3. Promising accessions identified during characterization of 36 genotypes of Brassica rapa L. (Brown sarson) genotypes grown during two seasons of 2013/2014 and 2014/2015 under rainfed conditions of Kashmir.

\begin{tabular}{ll}
\hline Trait & Promising genotypes \\
\hline Plant height & $>85.13:$ IC-363771, IC-538641, IC-363616-A, IC-553126 \\
No. of primary branches & $>3.3 \quad:$ IC- 363733, IC- 363735, IC- 212127, IC-553126 \\
Days to 50\% flowering & $>166.6:$ IC-553126, IC-259339, IC- 262824, IC- 363739 \\
No. of seeds/siliqua & $>13.46:$ IC- 280042, IC- 363735, IC- 363733, IC-223406-A \\
Seed yield/plant & $>9.005:$ IC- 363735, IC- 280048, IC- 343127, IC- 363739 \\
$1000-$ Seed weight & $>3.918:$ IC- 399823, IC-553126, IC- 363733, IC- 491555-A \\
\hline
\end{tabular}


Table 4. Summary Mean and LSD values of different agro-morphological traits of 36 Brassica rapa L. (Brown sarson) genotypes grown during two seasons of 2013/2014 and 2014/2015 under rainfed conditions of Kashmir.

\begin{tabular}{lllllll}
\hline Year & $\begin{array}{l}\text { Plant height } \\
\text { (cms) }\end{array}$ & $\begin{array}{l}\text { No. of } \\
\text { primary } \\
\text { branches }\end{array}$ & $\begin{array}{l}\text { Days to 50\% } \\
\text { flowering }\end{array}$ & $\begin{array}{l}\text { No. of seeds/ } \\
\text { siliqua }\end{array}$ & $\begin{array}{l}\text { Seed yield/ } \\
\text { plant (g) }\end{array}$ & $\begin{array}{l}\text { 1000-seed } \\
\text { weight(g) }\end{array}$ \\
\hline $2013 / 2014$ & 80.90 & 3.3 & 172.5 & 13.8 & 11.107 & 3.459 \\
$2014 / 2015$ & 70.12 & 3.1 & 161.6 & 10.1 & 10.310 & 3.500 \\
Mean & 75.51 & 3.2 & 167.1 & 11.9 & 10.710 & 3.479 \\
LSD at 5\% & 21.56 & 0.9 & 2.25 & 4.2 & 4.205 & 0.661 \\
\hline
\end{tabular}

Table 5. Correlation among different agro-morphological traits in 36 Brassica rapa L. (Brown sarson) genotypes grown during two seasons of 2013/14 and 2014/15 under rainfed conditions of Kashmir.

\begin{tabular}{lllllll}
\hline Parameter & Plant height & $\begin{array}{l}\text { No. of primary } \\
\text { branches }\end{array}$ & $\begin{array}{l}\text { Days to 50\% } \\
\text { flowering }\end{array}$ & $\begin{array}{l}\text { No. of seeds/ } \\
\text { siliqua }\end{array}$ & $\begin{array}{l}\text { Seed yield/ } \\
\text { plant }\end{array}$ & $\begin{array}{l}\text { 1000-Seed } \\
\text { weight }\end{array}$ \\
\hline Plant height & 1.000 & 0.514 & 0.145 & 0.222 & 0.070 & 0.262 \\
No. of primary branches & & 1.000 & -0.149 & 0.552 & 0.108 & 0.319 \\
Days to 50\% flowering & & 1.000 & 0.089 & 0.146 & -0.085 \\
No. of seeds/ siliqua & & & 1.000 & 0.232 & 0.009 \\
Seed yield/ plant & & & & 1.000 & -0.209 \\
1000-Seed weight & & & & & 1.000 \\
\hline
\end{tabular}

Table 6. Genetic parameters for six quantitative characters in 36 Brassica rapa L. (Brown sarson) genotypes grown during two seasons of 2013/2014 and 2014/2015 under rainfed conditions of Kashmir.

\begin{tabular}{llllllllll}
\hline S. N. & Trait & $\boldsymbol{\sigma}^{2} \mathbf{p}$ & $\boldsymbol{\sigma}^{2} \mathbf{g}$ & $\boldsymbol{\sigma}^{2} \mathbf{e}$ & $\mathbf{P C V}(\boldsymbol{\%})$ & $\mathbf{G C V}(\boldsymbol{\%})$ & $\mathbf{h}^{2}$ & $\mathbf{G A}$ & $\mathbf{G A}(\boldsymbol{\%})$ \\
\hline 1 & Plant height & 72.95 & 16.53 & 56.41 & 11.31 & 5.38 & 0.2266 & 3.99 & 5.28 \\
2 & No. of primary branches & 0.152 & 0.057 & 0.095 & 12.26 & 7.50 & 0.3750 & 0.30 & 9.47 \\
3 & Days to 50\% flowering & 0.850 & 0.235 & 0.615 & 0.551 & 0.29 & 0.2765 & 0.52 & 0.31 \\
4 & No. of seeds/ siliqua & 2.560 & 0.383 & 2.177 & 13.41 & 5.18 & 0.1496 & 0.49 & 4.14 \\
5 & Seed yield/ plant & 13.169 & 11.023 & 2.146 & 33.88 & 30.99 & 0.8370 & 6.28 & 58.63 \\
\hline
\end{tabular}

On the other hand 1000-seed weight remained almost unaffected by the time of sowing. The results corroborate with a recent study conducted during rabi 2011 2012 under temperate conditions of Kashmir in which early sowing of Brassica rapa L. on 1st October has taken more number of days to reach maturity as almost $80 \%$ plants started flowering almost two weeks earlier in late sown $\left(31^{\text {st }}\right.$ October) than in earlier sown seeds (Akhter et al., 2015). Rapeseed-Mustard has been found to be highly sensitive to changes in weather conditions as evidenced by variations in growth and yield components to different dates of sowing (Kumar et al., 2007). Mondal et al. (1999) have reported time of sowing to be very important in mustard production.Sowing at proper time provides optimum conditions for growth such as temperature, light, humidity and rainfall, thus being crucial in fully exploiting the genetic potential of a variety (Iraddi, 2008). Higher seed yields have been reported in $5^{\text {th }}$ October sowing than late sowing by about a month in Brassica juncea L. (Chahal et al., 2009).In different canola varieties a one month delay in sowing has been reported to decrease seed yield by 10 to $50 \%$ (Shargi et al., 2011). Correlation between traits is of interest to understand whether selection for one trait will have an effect on another. Simple correlation coefficients from the combined data across two years of 2013/2014 and 2014/2015 are shown in Table 5.Interestingly we have found a moderate negative correlation $(-0.209)$ between seed yield/plant and 1000-seed weight indicat- ing more the yield/plant lighter the seeds size and vice versa.

The pooled estimates of genetic parameters of variability; Phenotypic Coefficient of Variation (PCV), Genotypic Coefficient of Variation (GCV), Heritability in broad sense $\left(\mathrm{h}^{2}\right)$, Genetic advance $(\mathrm{GA})$ and Genetic advance as percentage of mean (GA \%) worked out to have a better understanding of the nature of the gene action for various traits are presented in Table 6.High range of variability, heritability, genetic advance and positive correlation coefficient among traits could be an excellent tool for selection of genotypes (Akbar et al., 2003).Studies of character association may supply more reliable information on the nature and level of interrelationships of yield with yield components (Jankulovska et al., 2014). Estimated values of PCV were higher than corresponding values of GCV for all characters because of variation due to environment as well as due to interactions; the magnitude of difference was comparatively lesser in the traits of seed yield/ plant and 1000-seed weight indicating lesser environmental influence on the expression of these traits. Higher PCV and corresponding GCV was recorded for the trait seed yield/plant implying enormous variability for this trait.On the other hand number of days to $50 \%$ flowering showed lowest PCV and GCV values indicating limited scope for selection of this trait. Heritability of an attribute provides an idea about its transmissibility from parents to off springs but it is the percentage of genetic advance that is more important to 
the breeder and together both are more reliable in selection (Shukla et al., 2006).The traits having high heritability with high genetic advance are considered under control of additive genes, whereas high heritability with low genetic advance are under control of nonadditive (dominant and/or epistatic) genes which limits the scope for improvement through selection (Akbar et $a l ., 2003)$. In the present study high heritability coupled with high to moderate genetic advance as per cent of mean was recorded for seed yield/plant and 1000seed weight indicating preponderance of additive gene action; the traits can thus be improved through simple selection. On the other hand moderate heritability with low genetic advance as per cent of mean was observed in all other traits viz., plant height, number of primary branches, days to $50 \%$ flowering and number of seeds/ siliqua indicating greater influence of environment; the selection thus would be ineffective. Characters showing high heritability along with moderate or low genetic advance could be improved by inter-mating superior genotypes of segregating population developed from combination breeding (Samadia, 2005).The intermating between selected segregates in advanced generations would help to accumulate favorable, desirable alleles for further improvement in seed yield and its component traits in Brown sarson.

\section{Conclusion}

Oil seed crop Brassica rapa L. (Brown sarson) has lot of scope for improvement in the state of Jammu and Kashmir in general and Kashmir valley in particular. The present study on 36 brown sarson genotypes has revealed maximum variability for seed yield/plant $(\mathrm{CV}$ $33.88 \%$ ) ranging from $3.840 \mathrm{~g}-18.470 \mathrm{~g}$. This trait also exhibited high heritability and genetic advance (\%).High heritability coupled with moderate genetic advance (\%) was also recorded for 1000 -seed weight indicating that both these traits can be improved through simple selection and that these characters could be used as selection criteria for improving overall yield of the crop. Promising genotypes identified based on these and other traits especially number of seeds/siliqua can be utilized directly in breeding programmes for genetic enhancement of this crop in the region.

\section{ACKNOWLEDGEMENTS}

The author is highly thankful to the Division of Evaluation, ICAR-INBPGR, New Delhi for supplying Brown sarson germplasm used in the present study.

\section{REFERENCES}

Akbar, M., Mahmood, T., Yaqub, M., Anwar, M., Ali, M. and Iqbal, N. (2003). Variability, correlation and path coefficient studies in summer mustard (Brassica juncea L.). Asian J. Pl. Sci., 2: 696-698.

Akhter, S., Singh, L., Rasool, R. and Ramzan, S. (2015).
Effect of date of sowing and varieties on yield of Brown Sarson (Brassica Rapa L.) under temperate Kashmir. International Journal of Engineering Science Invention, 4(3): 65-69.

Allard, R. W. (1960). Principles of plant breeding. John Wiley \& Sons, Inc. New York, p. 485.

Arunachalam, V. (1981). Genetic distance in plant breeding. Indian Journal of Genetics, 4:226-236.

Chahal, S. K., Dhaliwal, L. K., Singh, S. P. and Biswas, B. (2009). Effect of weather parameters on growth and yield of raya (Brassica Juncea L.). Abstracts and Souvenier $4^{\text {th }}$ National Seminar on Agrometreology-Needs, Approaches and linkages for rural development, CCS HAU, Hisar, pp15-16.

Dar, Z. A., Wani, S. A., Gul Zaffar, Habib, M., Ali, G., Sofi, P. A., Dar, S. A. and Iqbal, M. I. (2013). Analysis of combining ability in brown sarson (Brassica rapa L.) under temperate conditions. African Journal of Agricultural Research, 8(117): 603-1607.

DRMR (2015). Vision 2050 - Directorate of RapeseedMustard Research, Indian Council of Agricultural Research, Sewar, Bharatpur (India).

Iraddi, V. S. (2008). Response of mustard (Brassica juncea L. Czernj and Cosson) Varieties to date of sowing and row spacing in Northern transition zone of Karnataka. Thesis Submitted to the University of Agricultural Sciences, Dharwad In partial fulfilment of the requirements for the Degree of Master of science (Agriculture) In Agronomy, pp. 55-81.

Jankulovska, M., Ivanovska, S., Marjanovic-Jeromela, A., Bolaric, S., Jankuloski, L., Dimov, Z., Bosev, D. and Kuzmanovska, B. (2014) Multivariate analysis of quantitative traits can effectively classify rapeseed germplasm. Genetika, 46(2):545-559.

Joshi, A. B. and Dhawan, N. L. (1966). Genetic improvement of yield with special reference to self fertilizing crop. Indian Journal of Genetics and Plant Breeding 26: 101-113.

Kumar, G., Adak, T., Chakravarty, N. V. K., Chamola, R., Katiyar, R. K. and Singh, H. B. (2007). Effect of ambient thermal on growth and yield of Brassica cultivars. Brassica, 9 (1-4): 47-52.

Marjanovic-Jeromela, A., Kondic-Spika, A., SafticPankovic, D., Marinkovic, R., Hristov, N. (2009). Phenotypic and molecular evaluation of genetic diversity of rapeseed (Brassica napus L.) genotypes. African Journal of Biotechnology, 8 (19): 4835-4844.

Marjanovic-Jeromela, A., Marinkovic, R., Ivanovska, S., Jankulovska, M., Ankulovska, A. Mijtic, A., Hristov, N. (2011). Variability of yield determining components in winter rapeseed (Brassica napus L.) and their correlation with seed yield. Genetika, 43 (1): 51 - 66.

Mary, S.S. and Gopalan, A, (2006). Dissection of genetic attributes yield traits of fodder cowpea in F3 and F4. Journal of Applied Science and Research, 2: 805-808.

Ministry of Agriculture and Cooperation (2015). Statement on Production and demand of edible oils in India, Rajya Sabha, August $7^{\text {th }} 2015$.

Mondal, R.I., Biswas, M., Hydar A. M. K. and Akbar, M. A. (1999). Response of rapeseed genotype Dhali to seed rate and seeding date. Bangladesh Journal of Agricultural Research, 24(1): 83-90.

Nevo, E., Golenberg, E., Beilies, A., Brown, A. H. D. and 
Zohary, D. (1982). Genetic diversity and environmental associations of wild wheat. Triticum diococcoides in Israel. Theorotical and Applied Genetics, 62: 241-254.

Sadat, H. A., Nematzadeh, G. A., Jelodar, N. B., Chapi, O. G. (2010). Genetic evaluation of yield and yield components at advanced generations in rapeseed (B. napus L.). African Journal of Agricultural Research, 5(15): 19581964.

Samadia, D. K. (2005). Genetic variability studies in Lasora (Cordia myxa Roxb.). Indian Journal of Plant Genetic Resources, 18: 236-240.

Shargi, Y., Rad, A. H. S., Band, A. A., Noor Mohammadi, G. and Zahedi, H. (2011). Yield and yield components of six canola (Brassica napus L.) cultivars affected by planting date and water deficit stress. African Journal of Biotechnology, 10 (46): 9309-9313.
Shukla, S., Bhargava, A., Chatterjee, A., Sirivastava, J., Singh, N. and Singh, S. P. (2006). Mineral profile and variability in vegetable amaranth (Amaranthus tricolor). Pl. Foods Hum. Nut., 61: 23-28.

Singh, R. K. and Chaudhary, B.D. (1985). Biometrical Methods in Quantitative Analysis. Kalayani Publishers. New Delhi.

Singh, V., Singh, S. P., Singh, H., Hegde, D. M. and Tahir, T. A. (2007). Past progress, present scenario, nutritional value and strategies to enhance yield potential of rapeseed-mustard: an overview. Indian Journal of Crop Science 2(2): 245-247.

Wricke, G. and Weber, W. E. (1986). Quantitative genetics and selection in plant breeding. Walter de Gruyter \& Co. Berlin, Germany. 